\title{
THE HISTORY OF SCHISTOSOMIASIS RESEARCH AND POLICY FOR ITS CONTROL
}

\author{
by
}

F. R. SANDBACH*

\section{INTRODUCTION TO METHODOLOGY}

Schistosomiasis has been one of the most intensively studied parasitic diseases. No less than 10,286 citations of the disease were recorded in the 110 years following the discovery of the parasite in $1852 .{ }^{1}$ Despite the enormity of the literature, there has been no adequate study of the history of the disease and the policies aiming at its control. In 1973 a large collection of articles was published representing a selection from the medical literature pertaining to schistosomiasis during this period. ${ }^{2}$ This book included 384 abstracts of papers on schistosomiasis from 1852 to 1962 and an appendix which included further references to more recent literature up to 1972.

The collators of these abstracts have suggested two main purposes of the book. The first was as a major information source. Its use as such cannot be denied, as not only are many papers collected here which are very inaccessible, but also many of these abstracts have been derived from articles printed originally in a great variety of foreign languages. The second purpose of the book is more questionable as it purports to represent ". . . the process by which scientific information is both gathered and communicated". 8

The methodology used for collecting the abstracts was unusual. The use of citation indexes, indicating the popularity and importance of articles, was not adopted because of the magnitude and wide dispersal of the literature. Instead ". . . a large number of the best people working in the field ..."4 were chosen to select the most significant articles on the literature. The forty-seven selectors chosen produced a total of 9,671 citations. It was decided that the citations chosen six or more times should be the core of the selected-annotated bibliography. The selectors were then asked to suggest those citations which they felt were of particular importance and yet had not been part of the core. In addition, twenty of the original selections were omitted because of duplications and a consensus of opinion that they were not so relevant.

The methodological approach in representing the development of a medical

*F. R. Sandbach, B.Sc., M.Phil., Lecturer in Interdisciplinary Studies, The University of Kent at Canterbury, Keynes College, Kent CT2 7NP.

${ }^{1}$ For a complete bibliography of schistosomiasis research from 1852 to $1962 \mathrm{see}, \mathrm{K}$. S. Warren and V. A. Newill, Schistosomiasis: a bibliography of the world's literature from 1852 to 1962, San Francisco, University Press, 1967.

${ }^{2} \mathrm{~K}$. S. Warren, Schistosomiasis-the evolution of a medical literature. Selected abstracts and citations 1852-1972, Cambridge, Mass., Massachusetts Institute of Technology Press, 1973.

3 Ibid., p. ix.

I Ibid. 


\section{F. R. Sandbach}

literature can be criticized on two significant accounts. It is all too clear that the literature selected is presented as if science progressed without any major distortions. No abstracts, for instance, are included from the writings of those influential parasitologists, such as Looss and Sambon, who had held hypotheses about schistosomiasis transmission which were later to be disproved. Furthermore, a progressive view of the history of medical science fails to show how certain areas of investigation, such as social factors in the epidemiology of disease, became neglected. The book also fails to illustrate how the development of medical literature and policy is closely related to the social, economic and political context in which such developments take place. It is the purpose of this article to make good these omissions.

\section{A BACKGROUND TO THE LIFE-CYCLE AND EVOLUTION OF SCHISTOSOMIASIS}

There are three major parasitic species of schistosomiasis affecting the human population, namely Schistosoma haematobium, S. mansoni, and S. japonicum. ${ }^{5}$ These parasites have several characteristics of their life-cycle in common. Eggs, deposited by the parasite in the urine or faeces of the human host, find their way into water. On contact with water the eggs develop into miracidia. The miracidia are attracted to certain snails (the intermediate host) through chemical sensors and must penetrate a suitable snail within a matter of hours in order to survive, as the chance of survival of the miracidia falls off rapidly in all the schistosoma species after about ten hours. ${ }^{\circ}$

Inside the snail the parasite develops into sporocysts. After four to seven weeks within the snail the sporocysts start to liberate another free-living stage of the parasite called cercariae. The cercariae, like miracidia, also have a short life span of about forty-eight hours. During this time the cercariae must penetrate man or some other susceptible mammalian host (the definitive host) that comes in contact with the water. There is some indication that diurnal cycles of cercariae liberation have evolved as an adaptation to the social behaviour of the human host population. A study in Egypt has indicated that the peak activity of washing, bathing and playing amongst the local population occurred during the period of maximum cercariae liberation.? After penetrating the definitive host, the cercariae develop within six to twelve weeks into mature adult worms. Female mated worms then release eggs over a considerable period of time. While the average life-span of the mature female worm is believed to be around two to five years, they have been known to live from twenty to thirty years. ${ }^{8}$ The eggs are then excreted into the urine or faeces, thus completing the schistosome life cycle.

The differences between the schistosoma species are principally related to the different intermediate and definitive hosts that they infect and the location within the human host to which the parasites migrate. Broadly speaking, the main snail

- Other schistosoma species include $S$. intercalatum, $S$. matthei, $S$. margrebowiei, S. rodhaini and $S$. bovis. They are all of little public health significance except $S$. intercalatum which occurs in a few small foci in Africa. Other species may affect animals but are non-pathogenic to humans. See $\mathbf{M}$. $\mathbf{A}$. Stirewalt, 'Important features of the schistosomes', in N. Ansari (editor), Epidemiology and control of schistosomiasis, Basle, S. Karger, 1973, pp. 17-31.

- N. G. Hairston, 'The dynamics of transmission' in ibid., pp. 284-286.

7 M. Farooq and M. B. Mallah, 'The behavioural pattern of social and religious water contact activities in the Egypt-49 bilharziasis project area', Bull. Wld Hlth Org., 1966, 35: 377-387.

- For estimates of life span of the adult parasitic worm see Hairston, op. cit., note 6 above, p. 302. 


\section{History of Schistosomiasis research and policy for its control}

hosts of $S$. haematobium are those of the Bulinus species, ${ }^{9}$ and the adult worm develops in the veins of the human bladder. Consequently eggs are discharged through urination. Urine may find its way directly into the water through lack of sanitation and social custom. Activities such as swimming or fishing may increase the chances of infected urine reaching the water.

$S$. mansoni usually develops within Biomphalaria snail species, and the adult worm develops in the mesenteric vessels of the small intestine. Eggs are transmitted through the human faeces. Eggs within the faeces, deposited close to water, find their way into the water after a period of rain. The other main parasitic species, $S$. japonicum, usually develops in the Oncomelania snail, while the adult worm develops in the large intestine and, as in the case of $S$. mansoni, eggs are transmitted through human faeces. There is a great deal of difference between the range of definitive hosts that the parasite attacks. S. haematobium is almost specific to man, whereas the other two schistosoma species may be carried by a variety of mammalian hosts.

Knowledge of the schistosome life-cycle throws lights on the range of influences which will affect the transmission of the parasite. The presence, location and density of the intermediate snail host, together with other competing snails, are obviously important factors and clearly account for the geographical limitation of the parasites. For instance, $S$. haematobium is not found in South America because there is no suitable snail host. $S$. mansoni, carried there originally through the slave trade has become established because of the presence of susceptible hosts. On the other hand, the chances of the free-living stages of the parasite infecting the snail depend on a large number of social, economic and environmental factors.

The evolution of schistosomiasis itself probably occurred at the same time as the shift in human populations from hunter-gathering economies to societies based upon domestic agriculture. Survival of parasitism requires a stable relationship between host and parasite, such as is available in settlements close to slow-moving water in which the snail hosts of the disease abound. It is thought that the schistosome parasite first evolved around the Great Lakes of East Africa. ${ }^{10}$ An identifiable history of the disease dates back at least to the sixteenth century B.c. ${ }^{11}$

While there is no doubt that the Egyptians of 1,500 B.C. suffered from schistosomiasis, it is unlikely that the disease was very widespread at the time because of a lack of perennial irrigation and the consequent lack of suitable sites for transmission. ${ }^{12}$ However, despite the lack of perennial irrigation, the French soldiers of Napoleon Bonaparte, stationed in Egypt from 1799 to 1801, are known to have suffered severely

\footnotetext{
- For a complete list of the molluscan intermediate hosts of the schistosoma species see, W. H. Wright, 'Geographical distribution of schistosomes and their intermediate hosts', in Ansari, op. cit., note 5 above, pp. 37-38.

$10 \mathrm{G}$. S. Nelson, C. Teesdale and R. B. Highton, 'The role of animals as reservoirs of bilharziasis in Africa', in G. E. W. Wolstenholme and M. O'Connor (editors), Bilharziasis, Ciba Foundation Symposium, Boston, Little Brown, 1962, pp. 127-148.

11 P. B. Adamson, 'Schistosomiasis in antiquity', Med. Hist., 1976, 20 : 176-188.

12 El Halawani working at the World Health Organization Eastern Mediterranean Regional Office, Alexandria, Egypt, considered that the basin-type irrigation which was predominant at that time would not have allowed a wide distribution of the snail intermediate host. A. A. El Halawani, 'Bilharziasis as an integral part of rural health services' in Wolstenholme and O'Connor, op. cit., note 10 above, pp. 368-381.
} 


\section{F. R. Sandbach}

from haematuria which was almost certainly a result of schistosomiasis infection. ${ }^{13}$ Nevertheless, the schistosomiasis problem in Egypt did not become serious until the development of perennial irrigation after 1821, when there was a rapid increase in agricultural production and rural population. ${ }^{14}$

The presence of schistosomiasis in ancient Jericho has been used as an explanation for Joshua cursing the city and leaving it uninhabited in the late fourteenth century B.C. The biblical narrative refers to the dangers of the area, especially for children, the most likely age group to be affected by schistosomiasis. The city was reoccupied in the eighth century B.C. after a period of deteriorating climate which may well have destroyed the habitats of the snail. On the other hand, the biblical narrative refers to Elisha cleansing the well water with salts. It is possible that these salts also helped to destroy the snails. ${ }^{15}$

The historical change in the prevalence of schistosomiasis has altered dramatically in more recent times with the rapid development of large-scale irrigation projects. These projects have not only allowed a greater range of permanent habitats for the snail intermediate host, but have also caused more people to come in contact with infected water, either through greater population concentration or through greater access to water. In addition, migration of people from infected to uninfected areas has accentuated the increase in schistosomiasis. It is now generally agreed that there has been a rapid increase in the world prevalence of the disease, especially since the Second World War, and it has increased in many areas despite the implementation of costly control programmes. ${ }^{16}$ Numerous studies during the past sixty years have illustrated these changes. ${ }^{17}$ The interpretation of the factors involved in these changes has been crucial to the development of policies aimed at the control of schistosomiasis and can best be seen in the light of an historical survey of the literature on the epidemiology and control of the disease.

\section{EXTERNAL FACTORS IN THE DEVELOPMENT OF SCHISTOSOMIASIS RESEARCH AND POLICY}

As in the case of other tropical diseases, the history of schistosomiasis research and policy has been closely associated with colonialism and war. Early research was

13 See, S. G. Cowper, A synopsis of African bilharziasis, London, Lewis, 1971, pp. 2-3.

14 M. Farooq, 'Progress in bilharziasis control. The situation in Egypt', WHO Chron., 1967, 21 : 175-184.

${ }_{15} \mathrm{E}$. V. Hulse, 'Joshua's curse and the abandonment of ancient Jericho: schistosomiasis as a possible medical explanation', Med. Hist., 1971, 15: 376-386.

${ }_{16}$ P. Jordan, 'Epidemiology and control of schistosomiasis', Br. med. J., 1972, 28 : 55-59.

${ }^{17} \mathrm{See}$, for instance, the following articles. J. H. Jackson, 'Bilharzia, a background to its endemicity and control in Africa with particular reference to irrigation schemes', S. Afr. J. lab. clin. Med., 1958, 4: 1-54. J. N. Lanoix, 'Relation between irrigation engineering and bilharziasis', Bull. Wld Hlth Org., 1958, 17: 1011-1035. D. B. McMullen, Z. J. Buzo, M. B. Rainey, and J. Francotte, 'Bilharziasis control in relation to water resource development in Africa and the Middle East', ibid., 1962, 27: 25-40. R. F. Sturrock, 'The development of irrigation and its influence on the transmission of bilharziasis in Tanganyika', ibid., 1965, 32: 225-236. M. T. Farvar and J. P. Milton (editors), The careless technology - ecology and international development, New York, Natural History Press, 1972. H. El Nagar, 'Control of schistosomiasis in the Gezira Sudan', J. trop. Med. Hyg., 1957, 61: 231. M. Khalil Bey, 'The national campaign for the treatment and control of bilharziasis from the scientific and economic aspects', J. Egypt. med. Ass., 1949, 32: 820. K. D. B. Thompson, 'Rural health in Northern Nigeria. Some recent developments and problems', Trans. R. Soc. trop. Med. Hyg., 1967. $61: 277$. 


\section{History of Schistosomiasis research and policy for its control}

almost entirely the work of foreign doctors stationed primarily in Egypt but also in other North African countries and South Africa. The first impetus to medical work in Egypt had been felt during the French occupation in 1799. The Kasr el Aini Palace was then turned into a military hospital and later became the largest general hospital in Egypt. ${ }^{18}$ The French were also responsible for the creation of a medical school in Egypt. Clot Bey, who had arrived in Egypt as Surgeon-in-Chief to the French Army, founded the school in 1827. In the early days of the medical school all professors of medicine were foreign and had their lectures translated from French and German into Arabic. It was not until 1898, under the British administration of Egypt, that Arabic was replaced by English as the principal language for teaching purposes. The change in language was also accompanied by the replacement of Egyptian professors by new appointments from Britain. ${ }^{19}$

The main impetus to medical work and interest in schistosomiasis on the part of European countries followed the growth of empire building and the scramble for African territories during the last two decades of the nineteenth century. Between 1893 and the First World War four commissions, with the task of exploring the nature of the disease, were sent to North Africa from France, Germany, Italy and Great Britain. ${ }^{20}$ British interest in schistosomiasis arose shortly after the first major army campaigns of 1882 in Egypt and resulted directly from British concern with the administration of Egypt. The campaigns had followed riots between the Christian and Mohammedan communities. The Suez Canal was in jeopardy and a force of 4,000 marines landed to maintain order. Further campaigns in both Egypt and the Sudan thereafter became annual affairs. ${ }^{21}$ Coincidentally it was not until 1882 , twenty-three years after the first copy, that one finds any mention of the disease in the Lancet. A year later the reason became apparent to all: "This subject has become of considerable importance since the occupation of Egypt by our troops. Until then it was a condition of such rarity that few physicians in England had seen a case; in this part of the world it has always been a matter of great magnitude to the European settlers." 22

Imperial expansion was also accompanied by the migration of doctors abroad. By the end of the nineteenth century one-fifth of the doctors trained in Britain were practising their profession in warm countries and the growth of the Empire required further instruction in tropical medicine, the more so following the discovery of many agents of disease in the tropics. ${ }^{23}$ When Joseph Chamberlain went to the Colonial

18 J. D. Acland, 'Medical and physical society', St. Thomas's Hosp. Gaz., 1908, 18: 175-178.

10 N. Mahfouz, The life of an Egyptian doctor, Edinburgh, E. \& S. Livingstone, 1966, pp. $22,84$.

${ }^{20}$ Looss led the Commission from Germany, Lortet and Vialle from France, Sonsino from Italy and Leiper from Great Britain. R. T. Leiper, 'Reports on the results of the bilharzia mission in Egypt, 1915. Part I: transmission', J. R. Army med. Cps, 1915, 25: 1-55.

${ }^{21} \mathrm{~N}$. Cantlie, $A$ history of the army medical department, Edinburgh and London, Churchill Livingstone, 1974, p. 316.

22 J. F. Allen, 'Bilharzia haematobia', Lancet, 1883, i: 660.

23 P. H. Manson-Bahr, History of the school of tropical medicine in London 1899-1949, London School of Hygiene and Tropical Medicine: Memoir II, London, H. K. Lewis, 1956, p. 6. This list gives some examples of the more important discoveries: hookworm by Dubini in 1838; bilharzia haematobium by Bilharz in 1851; trypanosoma by T. Lewis in 1877; malaria by Laveran in 1880; cholera vibrio by Koch in 1883; plague bacillus by Kitasato and Yersin in 1894; trypanosoma brucei and its association with the Tse-Tse fly by Bruce in 1896; the development of malaria parasite in the mosquito by Ross in 1897. 


\section{F. R. Sandbach}

Office in 1895 he became impressed by the need to develop the colonies in a systematic manner. This was a new departure in foreign policy and was largely brought about by the increasing trade competition with the United States and Germany. ${ }^{24}$ In order to develop the colonies and to exploit the Empire's resources it became important to improve the health of the people and to extend scientific research. ${ }^{25}$ The combined pressure of colonial expansion, the health problems of the army and navy and the development of medical science led to the foundation of the tropical schools of medicine. The Liverpool School was opened in 1899 and the London School of Tropical Medicine was opened six months later. These were closely followed by schools in Antwerp and Amsterdam, as well as a hospital and institute in Hamburg.

In May 1899, at the inauguration of the London School of Tropical Medicine, Chamberlain said that " .... the study of tropical disease is a means of promoting Imperial policies". ${ }^{26}$ Patrick Manson, one of the main advocates of the creation of the school, saw its foundation in no less strong a light: “. . . [tropical medicine] will cheapen government and make it more efficient. It will encourage and cheapen commercial enterprise. It will conciliate and foster the native."27

Before the foundation of the schools of tropical medicine it had been difficult for research workers to meet and report their findings. Work was often undertaken in isolation from others in the same field of study and there was a lack of cross-fertilization of ideas. With the foundation of the schools, however, a concerted attack upon the diseases of the tropics could be made. ${ }^{28}$

The importance of schistosomiasis to soldiers during the Boer War was an additional stimulus to research work and resulted in the War Office sending R. T. Leiper from the London School of Tropical Medicine to Egypt, on a Bilharzia Mission at the beginning of the First World War, when the disease was menacing soldiers stationed in the Delta. ${ }^{29}$ Before the Second World War, research and policy had been confined to national programmes, especially in Egypt where institutions were adapted to deal specifically with schistosomiasis. It was not until 1942 that a specific schistosomiasis control programme was started in another country, Venezuela. ${ }^{30}$ However, just before the Second World War attempts were made to bring the problem of schistosomiasis to international attention. In 1938, Hilmy Bey, spokesman of the Egyptian delegation to the Health Organization of the League of Nations, proposed the establishment of a Schistosomiasis Commission to undertake work similar to

${ }^{24}$ L. Creswicke, The life of the Right Honourable Joseph Chamberlain, London, Caxton, 1904, p. 40.

${ }^{25} \mathrm{C}$. W. Forman, 'Science for empire: Britain's development of the empire through scientific research, 1895-1940', Ph.D. thesis, University of Wisconsin, 1941, p. 180.

26 The Times, 10 May 1899.

${ }^{27}$ Quoted in P. H. Manson-Bahr and A. Alcock, The life and work of Sir Patrick Manson, London, Cassell, 1927, p. 217.

${ }^{28}$ See, for instance, the experience of Manson, working alone in Formosa, as described by Manson-Bahr. P. H. Manson-Bahr, Patrick Manson, the father of tropical medicine, London, T. Nelson, 1962.

"Cowper, op. cit., note 13 above, p. 4. There was much distress from the disease during the Boer War and at the outbreak of the First World War pensions of $\$ 10,000$ per annum were still being paid to ex-servicemen who had acquired the disease. During the First World War soldiers gave the disease the slang name Bill Harris. W. D. Foster, A history of parasitology, Edinburgh, E. \& S. Livingstone, 1965, pp. 58, 65.

${ }^{\circ}$ M. Farooq, 'Historical development' in Ansari, op. cit., note 5 above, p. 12. 


\section{History of Schistosomiasis research and policy for its control}

that done by the Malaria Commission. ${ }^{31}$ The Health Committee reported on the disease and suggested that more research on the problems of epidemiology, prophylaxis, education and propaganda was necessary. ${ }^{32}$ Nothing came of these recommendations and the problem was not taken up by the League of Nations because the representation for action came only from Egypt, and also because of the imminence of war. ${ }^{33}$

The Second World War, however, brought schistosomiasis to international attention. Many allied soldiers were affected during military operations in China, the Philippines and the Pacific islands. At one time over 3,000 American soldiers were invalided home suffering from the disease, and it was estimated that the disease cost the American armed services over three million dollars during the war. ${ }^{34}$ Since then interest in schistosomiasis has been promoted by the United States National Institutes of Health and the Department of Defence, through both their own research and grants-in-aid.

As with other diseases, the impact of war aggravated the symptoms of schistosomiasis. An example of this has been shown in a study of fishermen on Lake Albert. These fishermen were constantly exposed to infection but in peace-time they remained in good condition, even though they had enlarged livers. During the war, however, they became undernourished and overworked and a grave epidemic of symptomatic schistosomiasis ensued. The epidemic ceased when the war ended, diet improved and work was reduced. ${ }^{35}$

The stimulus of the Second World War, the first assessment of the total world distribution of schistosomiasis (by N. Stoll in 1947) ${ }^{36}$ and the increased development of water resource projects and the associated increase in the prevalence of the disease combined to produce growing national and international concern. National programmes against schistosomiasis were adopted in Venezuela, Puerto Rico, Japan and Israel during and shortly after the war.

When the World Health Organization was set up after the war, representatives from Egypt again argued that schistosomiasis should be considered as a major international health problem. ${ }^{37}$ The economic importance of the disease was expressed in terms of its widespread incidence (it was believed at the time to affect up to 150 million people)

${ }^{\prime}$ A. Hilmy, Proposal to establish a schistosomiasis commission, Geneva, League of Nations Health Organization, C. H. 1351, 1938.

'Consultation of experts on bilharziasis (schistosomiasis), Geneva, League of Nations Health Organization, C. H. 1395, 1938.

A. T. Shousha, 'Schistosomiasis (bilharziasis). A world problem', Bull. Wld Hlth Org., 1949, 2: $19-30$.

i A. H. Abou-Gareeb, 'An epidemiological approach to the control of bilharzia', Indian J. publ. Hlth, 1958, 2: 280-294. Schistosomiasis was considered by the American armed forces to be a disabling disease. The story goes that up to $\$ 100$ was paid for a single sample of faeces to obtain deferment. J. F. Maldonado, Schistosomiasis in America, Barcelona, Editorial Cientifica-Medica, 1967, p. 4.

"C. Wilcocks, Aspects of medical investigation in Africa, Oxford, Oxford University Press, 1962, p. 44.

se Stoll estimated that 46 million people suffered from $S$. japonicum, 39.2 million from $S$. haematobium and 29.2 million from $S$. mansoni, giving a total of 114.4 million. N. Stoll, 'This wormy world', J. Parasit., 1947, 33: 1.

"Official records of the World Health Organization, No. 6., Interim Commission 4th Session, Geneva, 1948, p. 56. 


\section{F. R. Sandbach}

and in terms of its danger to domestic animals. ${ }^{88}$ At this time no attempt had been made to translate the disease burden of a community suffering from schistosomiasis into more precise economic terms. However, despite the lack of rigorous economic indicators, the Committee on Priorities decided in 1948 that schistosomiasis did warrant further attention. ${ }^{39}$ There was at first some disagreement as to whether schistosomiasis should be considered on its own or should be dealt with in conjunction with ankylostomiasis and filariasis, parasitic diseases with some similarities. The First World Health Assembly decided, largely on the basis that Egypt had spent more than six million dollars on schistosomiasis control measures in the previous five years, that an "Expert Committee" should be established to deal with schistosomiasis alone. ${ }^{40}$ During the ensuing post-World War period the World Health Organization has been the principal body concerned with the international support of research and control programmes.

SCHISTOSOMIASIS RESEARCH AND POLICY SINCE THE DISCOVERY OF THE PARASITE BY BILHARZ IN 1852

The development of fundamental ideas on the prevention of schistosomiasis between 1851 and the late 1960s began with the discovery of the schistosome parasite and ended with the final elucidation of the parasite cycle of the three main schistosoma species during the first year of the First World War. The literature during these years, despite representing less than five per cent of the total literature produced between 1852 and 1962,41 is consequently of paramount importance.

Theodor Maximilien Bilharz had discovered the parasitic worm in 1851 while working in the Kasr-El-Aini Hospital in Cairo and named it Distonum haematobium. $\mathrm{He}$ also discovered the connexion between the parasitic infection and previously known symptoms of the disease (dysentery and haematuria) which were a result of lesions in the intestine and bladder. ${ }^{42}$ Bilharz had observed eggs with lateral and terminal spines but thought they were liberated from the same parasitic worm. Patrick Manson later suggested that these were two distinctly different species and based his judgement on the different geographical distribution of the vesical (terminal spined eggs) and intestinal (lateral spined eggs) forms of the disease. ${ }^{43}$ Sambon suggested that the lateral spined eggs should be called S. mansoni on the basis of the differences between the eggs, geographical distribution and the associated symptoms other than just haematuria. ${ }^{44} R$. T. Leiper later confirmed the distinction between the species when he proved that they required different molluscan intermediate hosts. ${ }^{45}$

ss Shousha, op. cit., note 33 above, p. 22.

30 World Health Organization, op. cit., note 37 above, p. 215.

40 Official records of the World Health Organization, No. 13, Proceedings of the First World Health Assembly, Geneva 1948, p. 141.

4 Percentage figures taken from Warren and Newill, op. cit., note 1 above, p. xxxvi.

12 T. Bilharz, 'Further observations concerning Distonum Haematobium, from a letter to $C$. $T$. von Siebald', Z. Wissensch. Zool., 1853, 4: 454-456. An abstract in English may be found in Warren, op. cit., note 2 above, pp. 11-15.

is P. Manson, Tropical diseases: a manual, new and rev. ed., London, Cassell, 1903, pp. 605-606, 639.

" L. W. Sambon, 'Remarks on Schistosoma Mansoni', J. trop. Med. Hyg., 1907, 10: 303-304. L. W. Sambon, 'What is Schistosoma Mansoni', ibid., 1909, 12: 1-11.

${ }^{45}$ Leiper, op. cit., note 20 above, pp. 1-55. R. T. Leiper, "Reports on the results of the bilharzia mission in Egypt, 1915, Part 5: adults and ova", J. R. Army med. Cps, 1918, 30: 235-260. 


\section{History of Schistosomiasis research and policy for its control}

Before this discovery, however, much debate occurred as to the nature of any possible intermediate host. In 1854, Griesinger proposed that the "young" of Bilharzia would be found in the waters of the Nile, probably in fishes, bread, grain or fruit. The snail was first suggested as a possible intermediate host by Harley in 1864. His suggestion was essentially an extension of observations made by Professor Siebold on other trematode worms. ${ }^{46}$

The association of the disease with water was not in doubt but the reasons for this association most certainly were. Cobbold, Griesinger and Manson all argued that a mollusc was likely to be the intermediate host but they all met influential opposition from a distinguished German professor of parasitology called Looss, who had been studying the parasite between 1894 and 1914 in Egypt. Looss originally believed that there had to be an intermediate host but after searching in vain amongst the animals of the Nile Delta he adopted an alternative hypothesis. He suggested that the miracidium was the infective form for man and that an intermediate form developed in the liver. ${ }^{47}$

While Looss maintained his position over a long period of time it seemed untenable to Manson and others on the basis of geographical distribution. Sandwith, at the London School of Tropical Medicine, pertinently observed: “. . . It is remarkable that bilharziasis is one of the chief diseases of Africa and yet is so little distributed in Asia, where the conditions of climate and human life are so similar." ${ }^{48}$ It was later discovered that suitable intermediate hosts for schistosomiasis occurred only in very isolated parts of India, which confirmed Sandwith's suspicions.

Another false hypothesis was made by Sonsino, who in 1893 thought he had discovered the intermediate host. He had been working on small crustacea (amphypoda) and convinced himself that he had successfully infected these crustacea with the schistosome parasite, leading the science of schistosomiasis once again up a blind alley ${ }^{49}$ Balfour, following the work of Sonsino, also suggested that crustacea could act as intermediate hosts. ${ }^{50}$

Meanwhile, in the Far East, an allied disease, S. japonicum was being identified and the life-cycle tackled with notable success by Japanese investigators. ${ }^{51}$ In September 1913, Miyairi and Suzuki announced the experimental infection with miracidia of a dark-coloured snail found in the island of Kiysuki. ${ }^{52}$ Twelve days after infection rediae

4 Leiper, op. cit., note 20 above, p. 6.

47 . Miyairi, 'The intermediate host of Schistosoma Japonicum and the prophylaxis of schistosomiasis japonica', Tokyo lji Skinhsi [Tokyo med. J.], 1913, 1-8. Abstract in Warren, op. cit., note 2 above, pp. $1069-1071$.

${ }^{48}$ F. M. Sandwith, Medical diseases of Egypt, London, H. Kimpton, 1905, p. 215. 621.

1' P. Sonsino, 'Discovery of the life history of Bilharzia Haematobia (Cobbold)', Lancet, 1893, i:

${ }_{\text {so }}$ R. Girges, Schistosomiasis (bilharziasis), London, John Bale \& Danielson, 1934, p. 10.

s1 The clinical syndrome of the disease had been described in Japan by Fujii in 1847. The eggs were recognized by Majuna in 1888 and the adult worm by Fajuani in 1904. R. P. Strong, Stilt's prevention and cure of tropical diseases, London, H. K. Lewis, 2nd ed., 1944, p. 1426.

62 This beautiful, simple and conclusive experiment is described in R. T. Leiper, 'Medical helminthology, a review', Trop. Dis. Bull, 1923, 20: 859. The Japanese were at some advantage working with S. japonicum; not only was there just one species of parasite to contend with but this parasite infected a wide range of wild and domestic animals on which experiments could be performed. Such facilities were not available in Egypt. 


\section{F. R. Sandbach}

concentrated in the hepatic ducts of the snails. Mice were placed in the vessel in which the full-grown snails were fed. After three weeks numerous schistosomes were found in their livers. In 1914 a commission was sent by the London School of Tropical Medicine to observe the work of Miyairi and Suzuki. R. T. Leiper, Director of Parasitology, and Atkinson, his assistant, confirmed their work but had to cut short their visit because of the commencement of the First World War. ${ }^{53}$ In 1915, after the beginning of the war, Looss was banished by the English from Egypt, and the final solution was left to Leiper.

In the short period between 8 February and 15 July 1915 Leiper used the same techniques as those applied in Japan to work out the life-cycle of schistosomiasis in Egypt. Mainly using monkeys as expermimental mammalian hosts, he demonstrated that $S$. haematobium and $S$. mansoni were two distinct species and that they required different molluscan intermediate hosts. He showed conclusively that the terminal spined eggs of $S$. haematobium were associated with urinary bilharziasis, whereas the lateral spined eggs of $S$. mansoni were associated with the rectal or intestinal disease. ${ }^{54}$

By the end of the First World War basic research relevant to the choice of alternative policies had been established. It was known, for instance, that under "normal" conditions the peasant worker in Egypt was in continuous contact with schistosomiasis, that once infected he had some immunity to further infection, and that treatment might allow the possibility of reinfection. ${ }^{55}$ The implications of resistance have only recently been rediscovered in terms of concomitant immunity. ${ }^{56}$ It was also known that miracidia were attracted to certain snails, for in the words of Leiper: "Looss states that none of the Egyptian mollusca exhibited the slightest attraction for the freshly hatched miracidia of bilharzia. Most of the species submitted to experiment by us were entirely ignored by the miracidia. A definite attraction, however, was exhibited by the following: Planorbis boissyi, Bullinus sp. [?], Pyrgophysa forskali, and Limnaea truncataula. The attraction was stronger in young specimens. . .."5?

Such knowledge, had the implications been followed through, might have led to the discovery that the parasite could be transmitted by the presence of only a very few snails, thus making snail control a doubtful expedient due to the problems of completely eradicating snails in water bodies. ${ }^{58}$ The World Health Organization has recently become aware of the host-finding properties of the miracidia and recommended in 1966 that there should be more research into the "scanning" ability of

63 Girges, op. cit., note 50 above, p. 30.

s4 Leiper (1918), op. cit., note 45 above, pp. 235-260.

ss See for instance a report by F. Milton, 'Bilharzia its incidence and eradication', Lancet, 1920. i: 197. "His history will show that although he continues to expose himself to reinfection throughout the remainder of his life, he never again suffers the disease. This is the history of the vast majority of the natives of Egypt." At various periods of history, for example eighteenth-century Europe and ancient China, the presence of parasitic worms in the body was regarded by many people as beneficial. The reason no doubt was related to the resistance this conferred to reinfection. Foster, op. cit., note 29 above, p. 3.

se See for instance, S. R. Smithers, 'Recent advances in the immunity of schistosomiasis', Br. med. J., 1972, 28: 49-54.

${ }^{67}$ Leiper, op. cit., note 20 above, p. 38.

s8 It has been shown that transmission of schistosomiasis can occur in the presence of only very few snails. F. McCullough, 'Further observations on Bulinus (Bulinus) Truncatus Rohlfsi (claessim) in Ghana', Bull. Wld Hlth Org., 1962, 27: 169. 


\section{History of Schistosomiasis research and policy for its control}

miracidia. ${ }^{50}$ C. A. Wright, a leading expert on schistosomiasis and consultant to the World Health Organization, considers that the host-finding behaviour patterns of the miracidia and the reproductive potential of individual snails are now better appreciated and that one can no longer accept the existence of a safe lower limit to snail production. ${ }^{00}$

Before the life-cycle was discovered it was also common knowledge that social customs were important in the transmission of disease. In particular the opportunity for water contact was considered to be a crucial factor in explaining the epidemiology of schistosomiasis. As early as 1888, Allen was to write in the Practitioner "... that nearly all the youths bathing in the Unzindusi and Dorp sprid are infected, while the girls, who do not bathe, remain free of the disease". ${ }^{61}$ Sandwith also recognized that different groups of workers had different opportunities for water contact and consequently different degrees of schistosomiasis infection. ${ }^{62}$ During the early 1960 s, the importance of such factors was again rediscovered during a major World Health Organization sponsored project in Egypt. Several studies looked at water contact through swimming, washing utensils and clothes, and cattle herding, together with the social activity of which they were a part. The incidence of schistosomiasis varied between villages, occupations, ages and sexes. The differences could be accounted for by the different periods of contact with infected water. For instance, amongst different occupations, fishermen and boatmen had the greatest water contact and the highest infection rate, and Moslems, who practised ritual washing before prayers, had a higher infection rate than Christians. ${ }^{63}$ These studies, together with others in more recent years, ${ }^{64}$ have confirmed and elaborated upon facts which were widely known more than fifty years previously and yet were largely ignored in the period following the discovery of the life-cycle. To understand why certain areas of knowledge, including the host-finding properties of the miracidia, the immunity to reinfection of the human host, and the social factors in the epidemiology of disease became neglected areas of investigation, one must turn to a discussion of policies aimed at controlling schistosomiasis and how they reflected broader development policies. This discussion will focus primarily on policy in Egypt where most preSecond World War effort at controlling schistosomiasis took place.

so Epidemiology and control of schistosomiasis. Report of a WHO expert committee, Geneva 1966, Technical Report Series, No. 372, Geneva, 1967.

- C. A. Wright, 'Some biological views of the control of schistosomiasis', Trans. R. Soc. trop. Med. Hyg., 1969, 63: supp. 77-81.

i1 J. F. Allen, 'Parasitic haematuria or bloody urine', Practitioner, 1888, ii: 310-320.

e2 Sandwith, op. cit., note 48 above, p. 218.

as See, Farooq and Mallah, op. cit., note 7 above, pp. 377-387. M. Farooq, J. Nielson, S. A. Samaan, M. B. Mallah and A. A. Allam, 'The epidemiology of Schistosoma Haematobium and S. Mansoni infections in the Egypt-49 Project Area. Part II prevalence of bilharziasis in relation to personal attributes and habits', Bull. Wld Hlth Org., 1966, 35: 293-318. M. Farooq, J. Nielson, S. A. Samaan, M. B. Mallah and A. A. Allam, 'The epidemiology of Schistosoma Haematobium and $S$. Mansoni infections in the Egypt-49 Project Area. Part III prevalence of bilharziasis in relation to certain environmental factors', ibid., 1966, 35: 319-330.

"4 See for instance, W. R. Jobin and E. Ruiz-Tiben, 'Bilharzia and patterns of human contact with water in Puerto Rico', Boln. Assoc. Med. P. Rico, 1968, 60: 279-284. D. Pimental, C. E. Gerhardt, E. R. Williams, P. C. White and F. F. Ferguson, 'Aspects of schistosomal endemicity in three Puerto Rican watersheds', Am. J. trop. Med. Hyg., 1961, 10: 527. E. L. Hustings, 'Sociological patterns and their influence on the transmission of bilharziasis', Cent. Afr. J. Med., 1970, 16: supp. 5-10. 


\section{F. R. Sandbach}

POLICY FOR THE PREVENTION OF SCHISTOSOMIASIS IN EGYPT

Before the life-cycle of the schistosome parasite was finally determined, the predominant policy in preventing schistosomiasis was based on explanations of social and sanitary influences. Clearly if there were no intermediate host, as Looss maintained, and if no suitable drug existed for mass treatment of the human population, then the disease had to be prevented either by reducing the pollution of water or by avoiding contaminated water. This indeed was the generally accepted view of the time.65 However, implication of the snail in the transmission of the disease and the development of specific drugs for treating schistosomiasis suggested the possibility of alternative more technical approaches being adopted. For Leiper there was now a possibility of rapidly controlling the disease by eliminating the snail without involving the co-operation of the affected individuals. ${ }^{.6}$

Successful treatment of schistosomiasis patients during the First World War by Christopherson led him to believe that:

It is mass treatment in schools and villages where the hope of eradicating the disease lies. ... My own view is that there is more hope of successfully dealing with the schistosomiasis problem by the systematic treatment of individual cases wherever they are met than by attempting to eliminate the disease by the destruction of snails, which can only be a practicable proposition in limited areas where certain collections of water are known to be infected and which are the causes of immediate danger. ${ }^{87}$

The original programme against schistosomiasis in Egypt was to rely mainly upon mass treatment as the first expedient. Treatment was undertaken in the annexe of the Kasr el"Aini Hospital from December 1919, and by the end of the following year four hospitals had been established specifically for the treatment of schistosomiasis and ankylostomiasis (hookworm). These increased in number to eighteen in 1928 and fifty-six in $1951 .^{68}$ The number of patients treated rose rapidly between 1924 and 1930 but thereafter reached a plateau. Nevertheless over 300,000 people per year between 1933 and 1945 were treated in an attempt to reduce the disease. ${ }^{69}$ In the early part of the interwar period investigations into the feasibility of destroying the molluscan intermediate hosts took place within the Public Health Laboratories. Experimental work confirmed that weak solutions of copper sulphate were able to kill the snails and were not dangerous either to man or to the cotton and maize crops of Egypt. ${ }^{70}$

Sanitation and health education as measures to control disease were of only minor importance in the 1920s and 1930s. To begin with, provincial councils were encouraged to erect latrines and popularize their use. The Department of Public Health undertook the task of erecting latrines at its own expense in the village of Qalyub. However, despite the concern for building latrines these projects were reported to

${ }^{65}$ Girges, op. cit., note 50 above, p. 10. Leiper, op. cit., note 20 above, p. 47.

os See, ibid., p. 16. Lancet, 1919, i: 1032.

${ }^{67}$ C. G. K. Sharp, Schistosomiasis vel bilharziasis, (foreword by J. B. Christopherson), London, J. Bale, 1925.

${ }^{68}$ Research Institute and Endemic Diseases Hospital, first annual report, 1931, Ministry of the Interior, Cairo, Government Press, 1932, p. 1.

${ }^{60}$ Shousha, op. cit., note 33 above, p. 23.

${ }_{70}$ Ibid., p. 2, Reports and notes of the Public Health Laboratories, Cairo. Ankylostomiasis and bilharziasis in Egypt, Department of Public Health, Ministry of the Interior, Cairo, Government Press, 1924, pp. 110-112. 


\section{History of Schistosomiasis research and policy for its control}

have died in their infancy. ${ }^{71}$ A major project was then begun in 1928 under the joint auspices of the Rockefeller Foundation and the Egyptian government and included the introduction of bored-hole latrines in the houses of rural villages. The project was finally concluded in 1937 with no apparent beneficial results. ${ }^{72}$

Following the failure of sanitary measures and the first successful practical trials using copper sulphate to kill snails in the Dakhla oasis in 1927, proposals were forthcoming to adopt a concerted effort against the snail intermediate host. In 1941 the Ministry of Public Health finally set up a Bilharzia Snail Destruction Section within the Department of Public Health. This section quickly expanded its activities, using several hundred tons of copper sulphate every year until 1951, the last year of the reports. In 1952, with the restriction of finance and decreased availability of copper sulphate, the programme had to be restricted. ${ }^{73}$ The Bilharzia Snail Destruction Section had been confident that "... With the means at our disposal, it is possible to reduce the teeming snail populations to such an extent that they will not be able to carry out the schistosomiasis life-cycle successfully."74

However, the section made no attempt to determine whether the disease could still be transmitted by a small population of snails. In fact the most noticeable feature of the programme was that snail destruction was regarded as an end in itself. At no time was there any mention of the impact of the programme on the prevalence of the disease or on the welfare of the people. In actual fact it is extremely doubtful whether any of the measures adopted in Egypt before the late 1960s had any beneficial effect, as surveys between 1935 and 1937 and in 1967 indicated that there had been a massive increase in schistosomiasis. ${ }^{75}$ Emphasis upon snail control and mass treatment as opposed to broader sanitary and social methods of control does, however, help to explain the disregard for certain epidemiological information which was later to be rediscovered and emphasized in the 1960s. One can postulate that the external pressures for adopting specific measures for control were stronger than the internal logic of medical science. The external pressures were varied and deserve close attention.

Of prime importance was the development of the germ theory which held out the possibility of a quick, cheap and technical means of preventing disease. Experts in tropical medicine were preoccupied with the idea that disease could be stamped out by attacking the agents of disease, the parasites and intermediate hosts. ${ }^{76}$ Such

${ }^{71}$ Ibid., p. 66.

$72 \mathrm{~J}$. A. Scott and C. H. Barlow, 'Limitations to the control of helminth parasites in Egypt by means of treatment and sanitation', Am. J. Hyg., 1938, 27 : 619-646.

72 N. Ayad, 'The use of molluscicides in Egypt', Bull. Wld Hlth Org., 1961, $25: 713$.

"Third annual report of the bilharzia snail destruction section, 1944-45, Cairo, Government Press, 1947, p. 1.

${ }^{75}$ Farooq, op. cit., note 14 above, p. 175.

76 Patrick Manson, Medical Adviser to the Colonial Office from 7 July 1897, and one of the main advocates for the foundation of the schools of tropical medicine had ". . . shared in the pessimistic opinions then current about tropical colonisation by the white races. In recent years, however, his views on this subject had undergone a complete revolution. That revolution began with the establishment of the germ theory of disease. . . . He now firmly believes in the possibility of tropical colonisation by the white races. ... There was a weak and unprotected point in the life history of every parasite, on which, did he but know where it lies, man could place his finger and stay disease." 'The possibility of acclimatisation of Europeans in tropical countries', Br. med. J., 1898, i: 1168. See also, H. H. Scott, A history of tropical medicine, London, Edward Arnold, 1939, passim. 


\section{F. R. Sandbach}

approaches towards the prevention of diseases offered the possibility of cheaper and quicker methods of control than sanitary programmes. More often than not requests to the Colonial Office for finance to undertake sanitary programmes were turned down. ${ }^{77}$ Second there was the contemporary political conception of the African native as lazy, unintelligent and unco-operative. J. A. Hobson, writing in his classical book, Imperialism - a study, summarized this conception as follows: "The occupation of these new [African] territories was comprised in the presence of a small minority of white men, officials, traders and industrial organizers; exercising political and economic sway over great hoards of population regarded as inferior and as incapable of exercising any considerable rights of self-government, in politics or industry. ..."78

As a consequence of this widely adopted attitude and the exercise of political and economic control within a minority of officials, a technical means of controlling disease which did not involve the co-operation of the native was all the more important. Third, there was a strong belief that tropical diseases were related to the climate, that social behaviour was in large part determined by the climate, and that consequently education and social change would hardly be effective against such deterministic forces. ${ }^{79}$ This view was firmly expressed by Ali Bey, amongst others: "Schistosomiasis is a disease of warm countries; what is more natural and certain than that, in such places both the labourers and their children should drink freely, and bathe frequently in, the nearest water to hand?"80

Accepting social behaviour as unchangeable strongly favoured the adoption of technical means of schistosomiasis control. The fourth and related influence was the development of the medical profession which became dominated by biologists, parasitologists and other expert specialists. Training in tropical sanitation and hygiene became dominated by bacteriology, chemistry, entomology and protozoology, ${ }^{81}$ while sections within the Egyptian Research Institute developed along very differentiated and laboratory oriented lines, thus favouring the adoption of specific measures against the parasite and snail intermediate host. ${ }^{82}$ There were reactions to these developments but only of a limited nature. Ross had not gone along completely with the simple causal theory of disease of Manson and others. On the contrary, he was perhaps one of the last great bastions against specialism in medical science.

\footnotetext{
77 Ronald Ross, who discovered that the mosquito was the intermediate host of the malarial parasite, wrote on several occasions to Chamberlain begging him for more money to undertake sanitary programmes of reform. These requests were more often than not turned down. R. Ross, Memoirs, London, John Murray, 1923, passim.

78 J. A. Hobson, Imperialism - a study, London, George Allen \& Unwin, 1902, p. 27. Hobson considered that the development of imperialism negated the possibilities of self-government for these "inferior peoples".

79 Much of the recent work on medicine in less developed countries has been concerned with rejecting the still widely accepted view that tropical diseases are related to climate. The idea of tropical medicine itself, and the foundation of the National Schools of Tropical Medicine, reflected the idea that tropical diseases were related to tropical conditions, and especially climate. See J. Bryant, Health and the developing world, New York, Cornell University Press, 1969; M. King, Medical care in developing countries, Oxford, Oxford University Press, 1966.

${ }^{80}$ Ali Bey, 'The problem of bilharziasis in Egypt', J. st. Med., 1927, 5: 702.

${ }^{81}$ Manson-Bahr, op. cit., note 23 above.

"2 Five sections were created covering helminthology, protozoology, entomology, biochemical, and clinical aspects of disease. Research Institute ...., op. cit., note 68 above, p. 3.
} 


\section{History of Schistosomiasis research and policy for its control}

It is worth asking why. There is the scientist, with eyes to see but no brain to think, and the scientist with brains to think but no eyes to see; and the combination is rare. The biologist often does not possess the calculative faculty. Which Plato rightly decreed was essential to those who were to be admitted into his Academy. The doctor and the zoologist are trained rather in observation than in calculation; the one thinks in terms of medicine and the other in terms of classification and biomics. The doctor is often entirely ignorant of practical sanitation; he stands aghast before a few roadside puddles and the problems of town management, but delights in the idea of pouring quinine down everyone's throats for ever-especially if, as happens in certain foreign countries, he dispenses his own cures. The entomologist is busy over wing-veins and the pathologist over parasites; and the application to life-saving is apt to be of secondary interest to them. On the other hand, this is the sanitarian's principal motive, and he must be made up of calculation; he deals with men in the mass; he fits his measures to his means; and his great science of epidemiology should be largely a branch of applied mathematics. The question which is the best method for dealing with malaria in any one place or country is a sanitary question, to which medicine, parasitology, and entomology are ancillary. ${ }^{88}$

By the 1930s, however, many more writers were expressing their doubts as to the advantages conferred by specific measures of disease prevention. There was a growing interest in community development and in the economic and cultural improvement of the native population. ${ }^{84}$ The interest in wider aspects of development and the living conditions of the natives was reflected in a growing interest in the impact of nutrition on disease. ${ }^{85}$

During this period it also became apparent that there had been a general failure to meet the earlier expectations of rapid disease control. The mass treatment campaigns against schistosomiasis levelled off partly as a response to surveys which had failed to show any positive evidence that the numbers of persons infected had been reduced. ${ }^{86}$ Lack of success with other diseases such as malaria led to a renewed suggestion that disease was related more to standards of living than to the presence or absence of the disease agent. For instance, Sir Malcolm Watson was reported to say that: "...We must go further back and raise the living conditions of the natives; if that is done, as in England, so abroad, we may have better hope and expectation that "tropical diseases" so-called may disappear there as they have done in temperate climate."87

A reversion to an interest in social factors in the epidemiology of disease was not to last long. The institutional developments of medicine made it difficult to approach the problems of health education, and lack of expertise led to the failure of sanitary projects adopted in Egypt. The design of projects failed to take into consideration social factors in the pollution of water. Latrines were built in the villages, and yet the main place for defaecation and urination was clearly at the place of work, in the field. ${ }^{88}$ Barlow, who had been working on the sanitation project, recognized this

2 Ross, op. cit., note 77 above, pp. 431-432.

e Lord Hailey, An African survey, Oxford, Oxford University Press, 1938, passim. A. Beck, A history of the British medical administration of East Africa, 1900-1950, Cambridge, Mass., Harvard University Press, 1970, p. 14.

os ". . . the conclusion that the improvement of health in Africa is largely a question of better food supplies reflects the general tendency of medical science during the past few years". E. B. Worthington, Science in Africa, Oxford, Oxford University Press, p. 571.

" J. A. Scott, 'The incidence and distribution of the human schistosomes in Egypt', Am. J. Hyg., 1937, $25: 566-614$.

${ }^{87}$ H. H. Scott, op. cit., note 76 above, p. 1.

s8 Scott and Barlow, op. cit., note 72 above, pp. 614-646. 


\section{F. R. Sandbach}

failing but was much more impressed by the possibility of using molluscicides, as yet of limited importance, in controlling the disease. ${ }^{89}$

Just before and during the Second World War, there was considerable development of better drugs and artificial chemical insecticides, often at very low cost. After the war the use of these chemicals rekindled hopes of rapid disease control. As a consequence, tropical medicine once again became largely concerned with quick technical means of disease control..$^{20}$ Schistosomiasis policy itself became principally concerned with the use of molluscicides, and the importance of these was continually emphasized in reports of the World Health Organization.91

During the 1960s, however, various developments favoured a more widespread reaction to the use of technical measures of disease control in less developed countries. A growing concern for the environment in general and pesticides in particular led to a reaction against the widespread adoption of chemicals in the environment. Their effectiveness in controlling diseases such as malaria began to be challenged. ${ }^{92}$ Increasing awareness of pollution in streams and ponds through the use of chemicals has also revived an interest in biological means of snail control..$^{93}$

In the 1960s there was a renewed interest in community development as the less developed countries became independent fromt he metropolitan centres of the empires. This change, together with the interest in economic growth, the increasing costs of medical science, the radical changes in health policies in China and Cuba in particular, and the development of cost benefit analysis have all led to increasing concern with social and economic factors in the assessment of health programmes. ${ }^{94}$ As a consequence research workers have shown more interest in social factors in the epidemiology of disease, hence the rediscovery of basic knowledge about such things as the hostfinding properties of miracidia, the importance of water contact in the transmission of schistosomiasis and the whole study area of immunity to infection. It also became apparent that snail density is not so important a factor as it was once considered to be. ${ }^{95}$ Greater concern for community development has also led to a consideration of the economic importance of schistosomiasis. It can now no longer be assumed that

${ }^{80}$ First annual report. Bilharzia snail destruction section, 1942, Ministry of Public Health, Cairo, Government Press, 1945, p. 1.

${ }^{\circ 0}$ T. W. Meade, 'Medicine and population'. Publ. Hlth Lond., 1968, 72: 100.

-1 Joint OIHP/WHO study group on bilharziasis in Africa. Report on the first session (Cairo 1949,). Technical Report Series, No. 17, Geneva, WHO, 1950. Expert committee on bilharziasis. First report (San Juan, Puerto Rico, 1952). Technical Report Series, No. 65, Geneva, 1953. Molluscicides. Second report of the expert committee on bilharziasis (Geneva, 1960). Technical Report Series, No. 299, Geneva, 1965. Snail control in the prevention of bilharziasis, Monograph Series, No. 50, Geneva, 1965.

22 'Malaria and population', Lancet, 1968, i: 899. S. A. Meegana, 'Malaria eradication and its effects on mortality levels', Popul. Stud., 1967, 21: 207. F. Frederikson, 'Determinants and consequences of mortality and fertility trends', Publ. Hlth Lond., 1966, 81: 715-727.

${ }^{93} \mathrm{~J}$. D. Thomas, 'Schistosomiasis and the control of molluscan hosts of human schistosomes with particular reference to possible self-regulatory mechanisms', Adv. Parasitol., 1973, 11: 311.

${ }^{94} \mathrm{E}$. Ammundsen and K. W. Newell, 'Health service development in the third world', WHO Chron., 1975, 29: 10. B. A. Weisbrod, R. L. Andreano, R. E. Baldwin, E. H. Epstein, and A. C., Kelley, Disease and economic development: the impact of parasitic diseases in St. Lucia, Madison University of Wisconsin Press, 1973.

${ }^{95}$ See for instance, McCullough, op. cit., note 58 above, p. 161. 


\section{History of Schistosomiasis research and policy for its control}

the disease is always of serious public health concern. ${ }^{96}$ Furthermore, a consideration of the social factors in the epidemiology of schistosomiasis, together with the external costs and benefits of alternative projects, has begun to influence the choice of control projects. ${ }^{97}$ Nevertheless the impetus behind snail control and mass treatment has continued. In 1972, at an international symposium on schistosomiasis, a review of current projects aimed at controlling schistosomiasis in fifteen countries revealed that in twenty-two projects molluscicides were used; in ten engineering methods were used to control snails; in fifteen chemotherapy was employed; and in only ten projects were sanitary and health education policies applied. The consensus amongst the majority of schistosomiasis experts at the conference was also that the use of molluscicides should "... be given major consideration in the planning of control programmes." 98

\section{CONCLUSION}

In the case of a disease such as schistosomiasis the history of research and policy is inextricably bound up with factors outside the discipline of medical science. Such influences as imperialism, war, development policy and the institutional organization of medical research have in the past focused attention on biological factors in the transmission of the parasite at the expense of social factors, with the major exceptions of a brief period in the 1930s and, more recently, of the last decade. To understand the history of science one must not be solely concerned with the internal development within the disciplines of science but must interpret such developments in a much broader social context.

${ }^{96}$ R. Foster, 'Schistosomiasis on an irrigated estate in East Africa', J. trop. Med. Hyg., 1967, 70: 185. A. Fenwick, 'Control of Schistosoma mansoni on an irrigated estate in East Africa', Ph.D. thesis, Liverpool University, 1971. B. Essex, 'The social and economic aspects of schistosomiasis with reference to health planning in developing countries', M.Sc. Report, London School of Economics, 1972. R. E. Baldwin and B. A. Weisbrod, 'Disease and labour productivity', Economic Developmental and Cultural Change, 1974, 22: 414. Weisbrod et al., op. cit., note 94 above. E. H. Epstein and B. A. Weisbrod, 'Parasitic diseases and academic performance of schoolchildren', Social \& econ. Stud., 1974, 23 : 551.

" Jordan, op. cit., note 16 above, p. 55.

${ }^{28} \mathrm{~J}$. M. Miller (editor), Proceedings of a symposium on the future of schistosomiasis control, New Orleans, Tulane University Press, 1972. 